\title{
Global patterns in phytoplankton community size structure - evidence for a direct temperature effect
}

\author{
Erik Askov Mousing ${ }^{1, *}$, Marianne Ellegaard ${ }^{2}$, Katherine Richardson ${ }^{3}$ \\ ${ }^{1}$ Center for Macroecology, Evolution and Climate, Department of Biology, University of Copenhagen, Universitetsparken 15, \\ 2100 Copenhagen Ø, Denmark \\ ${ }^{2}$ Marine Biological Section, Department of Biology, University of Copenhagen, Øster Farimagsgade 2D, \\ 1353 Copenhagen $K$, Denmark \\ ${ }^{3}$ Center for Macroecology, Evolution and Climate, University of Copenhagen, Natural History Museum of Denmark, \\ Universitetsparken 15, 2100 Copenhagen Ø, Denmark
}

\begin{abstract}
In this study, a global data set on size-fractionated chlorophyll distributions collected in the open ocean (depth $>400 \mathrm{~m}$ ) is used to investigate phytoplankton community size structure in relation to temperature and inorganic nutrient availability in an attempt to identify the individual and shared effects of these 2 factors. The macroecological patterns show an increase in the fraction of large phytoplankton with increasing nutrient availability and a decrease with increasing temperature. We empirically demonstrate that temperature has both a nutrient-independent effect and a nutrient-shared effect on phytoplankton community size structure. We argue that the nutrient-independent effect is likely a direct effect of temperature, whereas the nutrient-shared effect may be an indirect effect of temperature (where thermal stratification influences the introduction of nutrients to surface waters). When regional differences in the average contribution of large cells were accounted for, the nutrient-independent effect of temperature explained $8 \%$ of the variation in phytoplankton community size structure compared with the $23 \%$ explained by the nutrient-shared effect. The results suggest that the relationship between phytoplankton community size structure and temperature change is the same in all ocean regions and leads to a decrease in the relative contribution of large cells in the community as temperature increases regardless of ambient nutrient availability. As phytoplankton size is an important factor influencing carbon transport to the deep ocean, it is important to incorporate any possible direct temperature effect on phytoplankton community size composition in models addressing carbon flow and metabolism in a warming ocean.
\end{abstract}

KEY WORDS: Phytoplankton · Community size structure $\cdot$ Temperature effect . Climate change · Variance partitioning $\cdot$ AIC $\cdot$ Macroecology

\section{INTRODUCTION}

Phytoplankton size is a fundamental biological trait that influences community size structure (Petchey et al. 2008) as well as many physiological and ecological processes (e.g. metabolic rates, nutrient acquisition, sinking rates, grazing etc.) at the species, population and community scales (Brown et al. 2004, Petchey et al. 2008, Reuman et al. 2008). Phytoplankton community size structure, in turn, influences carbon cycling in the ocean and, thereby, the global carbon cycle (Michaels \& Silver 1988, Laws et al. 2000, Hilligsøe et al. 2011). Understanding the mechanisms controlling phytoplankton community size structure and how size structure may interact with climate change is thus imperative for predicting future ocean function. 
Phytoplankton community size structure has been shown to change with temperature, with the importance of small cells in the community increasing with temperature, both temporally (Finkel et al. 2005, 2007, Winder et al. 2009) and spatially in the ocean (Daufresne et al. 2009, Morán et al. 2010, Hilligsøe et al. 2011), and in mesocosm (Sommer \& Lengfellner 2008, Yvon-Durocher et al. 2011, Peter \& Sommer 2012) and microcosm experiments (Peter \& Sommer 2012). Furthermore, the body size of ectotherms is known to decrease with increasing temperature. This is referred to as the temperature-size rule (Atkinson 1994). Hence, in a metaanalysis of laboratory studies, Atkinson et al. (2003) found a cell size reduction in aquatic protists of ca. $2.5 \%$ for each $1^{\circ} \mathrm{C}$ increase, which did not differ across taxa, habitats or modes of nutrition. Peter \& Sommer (2012) recently reported that the decrease in cell size was much larger than that found by Atkinson et al. (2003) when natural assemblages were investigated, and concluded that this was due to genetic variability within species.

Despite this consistent pattern, researchers have so far failed to reach consensus on the pathways by which temperature mitigates this temperature-size pattern. This is because of the negative relationship between temperature and nutrient availability in the open ocean (Kamykowski \& Zentara 1986, Li 1998, Behrenfeld et al. 2006), which makes it difficult to discern and quantify the individual effects of these factors on phytoplankton community size structure. Although a few studies have hinted at a direct effect of temperature on community size structure in nature (e.g. Morán et al. 2010, Hilligsøe et al. 2011), the current paradigm still states that there is no significant direct effect of temperature on phytoplankton community size structure, and the temperature-size relationship is therefore usually explained as an indirect effect, i.e. through the development of stratification and its resulting influence on nutrient availability (e.g. Finkel et al. 2005, 2007, Marañón et al. 2012).

Regardless of the current paradigm, there are at least 2 non-exclusive mechanisms whereby temperature might directly affect phytoplankton community size structure. Firstly, metabolic rates are correlated with both temperature and cell size (Gillooly et al. 2001), with $Q_{10}=1.88$ for phytoplankton over a moderate range of temperatures (Eppley 1972). All things being equal, an increasing metabolic rate will increase resource demand and, therefore, competition for nutrients. This might give smaller species an advantage due to a smaller diffusion boundary layer and a large surface to volume ratio (Tilman et al.
1982, Kiørboe 1993). In support of a temperature effect on competitive exclusion, Hillebrand (2011) found that increasing temperature would accelerate competitive displacement and alter the species composition in benthic microalgae, indicating that warming might influence outcome and temporal dynamics in species interactions. The mechanism hypothesized here, i.e. increased intraspecific and interspecific competition for limiting resources, is the same as that in the usually adopted assumption that the temperature effect on phytoplankton community size structure is indirect and operates through thermal stratification and a resulting decrease in nutrient availability. In other words, both increasing cellular nutrient requirements (i.e. increasing metabolic rates as a function of temperature) and a decrease in the concentration of nutrients in the euphotic zone (through stratification) can be predicted to result in increasing resource competition and a smaller community mean cell size.

The second mechanism through which temperature may be predicted to influence phytoplankton community size structure is a change in the relative demand for nutrients by different organism groups. Temperature changes affect the maximum growth rate of photoautotrophs and heterotrophs differently, with the response being stronger for heterotrophs (Rose \& Caron 2007). Increasing temperature might, therefore, increase resource competition between autotrophic and heterotrophic organisms and increase the ability of herbivorous protists to exercise top-down control on specific size classes within the phytoplankton community, thereby influencing community size structure.

In the light of the increasing temperatures being recorded in the world's oceans, it is important to understand the mechanism(s) of interaction between temperature and phytoplankton community size structure. Therefore, in this study, we analyze global patterns of phytoplankton community size structure in relation to temperature and inorganic nutrient availability in an attempt to disentangle the individual effects of these 2 factors. To do this, we reexamine data presented in Hilligsøe et al. (2011), taking into account the limitations set by spatial dependence (autocorrelation). The focus of this effort is to identify and quantify the relative importance of a potential direct effect in relation to the nutrientshared effect of temperature and to assess whether the effect of increasing temperature can be considered universal, as such an effect could have profound implications for modeling projected effects of global change. 


\section{MATERIALS AND METHODS}

\section{Hydrology and sampling}

Samples used in this study were collected during the circumnavigating Galathea 3 expedition on HDMS 'Vædderen' carried out in 2006-2007 and on a cruise with RV 'Dana' in August 2008 in the Northern At- lantic (Table 1). Conductivity, temperature and depth were measured using a Seabird Instruments 911 system. The instruments were attached to a rosette of 12 Niskin bottles (30 l). Only stations with water depths greater than $400 \mathrm{~m}$ were used in the analysis, in order to restrict the possible influence of anthropogenic activities (i.e. eutrophication and changed N/P/Si ratios) on phytoplankton community size structure.

Table 1. Station coordinates and ocean regions ordered by sampling date. EA: Eastern Atlantic; EP: Eastern Pacific; IOS: Indian Ocean Sector; NEA: Northeastern Atlantic; NWA: Northwestern Atlantic ${ }_{i}$ SO: Southern Ocean; WP: Western Pacific; WA: Western Atlantic

\begin{tabular}{|c|c|c|c|c|c|c|c|c|c|}
\hline Station & $\begin{array}{l}\text { Latitude } \\
\quad\left({ }^{\circ}\right)\end{array}$ & $\begin{array}{l}\text { Longitude } \\
\left.\quad{ }^{\circ}\right)\end{array}$ & $\begin{array}{c}\text { Date } \\
\text { (yyyy/mm/dd) }\end{array}$ & $\begin{array}{l}\text { Ocean } \\
\text { region }\end{array}$ & Station & $\begin{array}{c}\text { Latitude } \\
\quad\left({ }^{\circ}\right)\end{array}$ & $\begin{array}{l}\text { Longitude } \\
\left(^{\circ}\right)\end{array}$ & $\begin{array}{c}\text { Date } \\
\text { (yyyy/mm/dd) }\end{array}$ & $\begin{array}{l}\text { Ocean } \\
\text { region }\end{array}$ \\
\hline 1 & 61.391 & -3.443 & 2006/08/16 & NEA & 45 & -67.278 & -83.020 & $2007 / 01 / 22$ & $\mathrm{SO}$ \\
\hline 2 & 62.038 & -9.996 & $2006 / 08 / 18$ & NEA & 46 & -63.902 & -61.633 & $2007 / 01 / 27$ & $\mathrm{SO}$ \\
\hline 3 & 62.165 & -16.573 & $2006 / 08 / 18$ & NEA & 47 & -62.965 & -58.050 & $2007 / 01 / 29$ & $\mathrm{SO}$ \\
\hline 4 & 62.516 & -33.309 & $2006 / 08 / 20$ & NEA & 48 & -62.319 & -57.748 & $2007 / 01 / 30$ & $\mathrm{SO}$ \\
\hline 5 & 60.230 & -48.467 & $2006 / 08 / 26$ & NWA & 49 & -58.802 & -60.900 & $2007 / 01 / 30$ & $\mathrm{SO}$ \\
\hline 6 & 65.835 & -56.565 & $2006 / 08 / 31$ & NWA & 50 & -57.928 & -61.870 & $2007 / 01 / 31$ & $\mathrm{SO}$ \\
\hline 7 & 66.905 & -53.289 & 2006/09/04 & NWA & 51 & -38.105 & -74.125 & $2007 / 02 / 07$ & $\mathrm{EP}$ \\
\hline 8 & 62.110 & -50.977 & 2006/09/12 & NWA & 52 & -29.286 & -71.883 & $2007 / 02 / 12$ & EP \\
\hline 9 & 53.783 & -38.384 & $2006 / 09 / 14$ & NWA & 53 & -26.304 & -71.262 & $2007 / 02 / 12$ & EP \\
\hline 10 & 40.692 & -28.814 & 2006/09/16 & NEA & 54 & -20.057 & -70.755 & $2007 / 02 / 17$ & EP \\
\hline 11 & 38.004 & -27.000 & 2006/09/17 & NEA & 55 & -17.086 & -72.419 & $2007 / 02 / 18$ & EP \\
\hline 12 & 33.768 & -25.415 & $2006 / 09 / 22$ & NEA & 56 & -13.872 & -76.804 & $2007 / 02 / 22$ & EP \\
\hline 13 & 23.079 & -24.052 & $2006 / 09 / 24$ & EA & 57 & -14.163 & -77.429 & $2007 / 02 / 24$ & $\mathrm{EP}$ \\
\hline 14 & 12.206 & -21.023 & $2006 / 09 / 26$ & EA & 58 & -5.254 & -81.578 & $2007 / 03 / 01$ & EP \\
\hline 15 & 1.627 & -10.524 & $2006 / 09 / 29$ & EA & 59 & 0.009 & -85.450 & $2007 / 03 / 03$ & EP \\
\hline 16 & 4.741 & -0.331 & $2006 / 10 / 02$ & EA & 60 & 5.330 & -84.115 & $2007 / 03 / 09$ & $\mathrm{EP}$ \\
\hline 17 & -4.932 & 4.483 & $2006 / 10 / 08$ & EA & 61 & 6.665 & -80.997 & $2007 / 03 / 10$ & $\mathrm{EP}$ \\
\hline 18 & -7.430 & 5.552 & 2006/10/09 & EA & 62 & 10.700 & -79.026 & $2007 / 03 / 12$ & WA \\
\hline 19 & -12.512 & 7.807 & $2006 / 10 / 10$ & EA & 63 & 17.025 & -67.794 & $2007 / 03 / 14$ & WA \\
\hline 20 & -27.885 & 14.656 & $2006 / 10 / 13$ & EA & 64 & 19.000 & -63.999 & $2007 / 03 / 29$ & WA \\
\hline 21 & -38.486 & 31.715 & $2006 / 10 / 21$ & IOS & 65 & 22.044 & -64.005 & $2007 / 03 / 30$ & WA \\
\hline 22 & -39.564 & 42.746 & $2006 / 10 / 23$ & IOS & 66 & 26.501 & -64.001 & $2007 / 04 / 01$ & WA \\
\hline 23 & -37.259 & 72.507 & $2006 / 10 / 27$ & IOS & 67 & 27.660 & -63.997 & $2007 / 04 / 02$ & WA \\
\hline 24 & -31.406 & 91.178 & $2006 / 10 / 30$ & IOS & 68 & 28.502 & -67.004 & $2007 / 04 / 03$ & WA \\
\hline 25 & -29.582 & 95.249 & $2006 / 10 / 31$ & IOS & 69 & 26.501 & -66.998 & $2007 / 04 / 04$ & WA \\
\hline 26 & -24.468 & 105.236 & $2006 / 11 / 02$ & IOS & 70 & 25.003 & -67.002 & $2007 / 04 / 05$ & WA \\
\hline 27 & -34.380 & 114.411 & $2006 / 11 / 24$ & IOS & 71 & 24.991 & -69.997 & $2007 / 04 / 06$ & WA \\
\hline 28 & -33.497 & 128.393 & $2006 / 11 / 29$ & IOS & 72 & 27.030 & -70.090 & $2007 / 04 / 07$ & WA \\
\hline 29 & -35.174 & 132.617 & $2006 / 12 / 03$ & IOS & 73 & 28.993 & -69.997 & $2007 / 04 / 08$ & WA \\
\hline 30 & -37.295 & 139.673 & $2006 / 12 / 04$ & IOS & 74 & 32.508 & -70.027 & 2007/04/09 & WA \\
\hline 31 & -42.572 & 149.667 & $2006 / 12 / 05$ & WP & 75 & 44.334 & -56.176 & $2007 / 04 / 16$ & WA \\
\hline 32 & -37.921 & 151.140 & $2006 / 12 / 09$ & WP & 76 & 44.328 & -48.958 & $2007 / 04 / 17$ & WA \\
\hline 33 & -31.515 & 153.412 & $2006 / 12 / 14$ & WP & 77 & 44.395 & -47.444 & 2007/04/18 & WA \\
\hline 34 & -14.213 & 156.859 & $2006 / 12 / 18$ & WP & 78 & 53.490 & -23.331 & $2007 / 04 / 21$ & NEA \\
\hline 35 & -10.702 & 157.482 & $2006 / 12 / 20$ & WP & 79 & 56.186 & -15.234 & $2007 / 04 / 22$ & NEA \\
\hline 36 & -10.179 & 157.594 & $2006 / 12 / 21$ & WP & 80 & 62.633 & -40.510 & $2008 / 08 / 06$ & NWA \\
\hline 37 & -7.824 & 156.069 & $2006 / 12 / 27$ & WP & 81 & 62.621 & -37.892 & $2008 / 08 / 07$ & NWA \\
\hline 38 & -29.046 & 164.427 & $2007 / 01 / 07$ & WP & 82 & 62.560 & -35.239 & $2008 / 08 / 07$ & NWA \\
\hline 39 & -36.003 & 170.860 & $2007 / 01 / 05$ & WP & 83 & 62.515 & -32.680 & 2008/08/08 & NEA \\
\hline 40 & -49.695 & 178.877 & $2007 / 01 / 12$ & $\mathrm{SO}$ & 84 & 62.444 & -30.122 & 2008/08/08 & NEA \\
\hline 41 & -55.636 & 167.539 & $2007 / 01 / 14$ & $\mathrm{SO}$ & 85 & 62.389 & -27.524 & 2008/08/08 & NEA \\
\hline 42 & -61.827 & 150.931 & $2007 / 01 / 16$ & $\mathrm{SO}$ & 86 & 62.340 & -24.930 & 2008/08/09 & NEA \\
\hline 43 & -64.583 & -132.385 & $2007 / 01 / 18$ & $\mathrm{SO}$ & 87 & 62.293 & -22.336 & $2008 / 08 / 09$ & NEA \\
\hline 44 & -66.590 & -108.931 & $2007 / 01 / 20$ & $\mathrm{SO}$ & 88 & 62.237 & -19.729 & 2008/08/10 & NEA \\
\hline
\end{tabular}




\section{Chlorophyll a determination and size fractionation}

On the Galathea 3 expedition, total chlorophyll $a$ (chl a) and size fractions of chl a were determined in the surface water, at the depth of the chl a maximum (DCM), at standard sampling depth below the chl a maximum (1.5 times the depth of the DCM minus $10 \mathrm{~m}$ ), and at $30 \mathrm{~m}$ at selected stations. On the Dana 2008 cruise, chl $a$ and size-fractionated chl a were determined in the surface water and at DCM. Seawater was tapped from the Niskin bottles and filtered through Whatman GF/F and $10 \mu \mathrm{m}$ pore size filters. For each sampling depth and filter size, triplicate filtrations of 200-500 ml seawater for the GF/F filters and $400-1000 \mathrm{ml}$ seawater for the $10 \mu \mathrm{m}$ filters were performed. The samples were extracted for a minimum of $6 \mathrm{~h}$ in $5 \mathrm{ml}$ ethanol (96\%) in the dark at room temperature. The absorbance was measured on a TD-700 fluorometer (Turner Designs), which was calibrated against a pure chl a standard. Calculations of chl a from the absorbance follow method 445.0 of the United States Environmental Protection Agency. The fraction of phytoplankton larger than $10 \mu \mathrm{m}$ (in the following referred to as the fraction of large phytoplankton) was then calculated as the fraction of chl $a$ retained on a $10 \mu \mathrm{m}$ filter divided by the fraction of chl a retained on a GF/F filter. Thus, the fraction of large phytoplankton is used in this study as a proxy for phytoplankton community size structure where an increase in this fraction is interpreted as an increase in the relative contribution of large phytoplankton cells to the total phytoplankton biomass.

\section{Inorganic nutrient determination}

Seawater was tapped from the Niskin bottles and immediately frozen. Subsequent analyses were performed on land at the National Environmental Research Institute, University of Aarhus, Denmark. The samples were filtered through Millipore Millix-GP Hydrophilic PES $0.22 \mu \mathrm{m}$ filters and analyzed for nitrate, nitrite, ammonium and phosphate by wetchemistry methods according to Grasshoff et al. (1983) with a SANPLUS System Scalar auto-analyzer. The detection limits were $0.1,0.04,0.3$ and 0.06 for nitrate, nitrite, ammonium and phosphate, respectively.

\section{Statistical analyses}

In total, 260 pair-wise observations of the fraction of large phytoplankton and inorganic nutrient availabil- ity were used in this analysis. All statistical analyses were carried out with the free software R (R Core Development Team 2012). In order to investigate the importance of temperature and inorganic nutrients in explaining the fraction of large phytoplankton, we used bivariate and multivariate linear modeling. All variables with the exception of temperature were logtransformed to meet model assumptions of linearity, homogeneity of variance and residual normality, and the data were fitted using ordinary least squares estimation. Offsets used in the transformation were $\delta_{\text {Total inorganic nitrogen }}=0.04$ and $\delta_{\text {Phosphate }}=0.06$ (Hilligsøe et al. 2011). Models were validated using visual inspection (i.e. investigation of the residual patterns versus fitted values and theoretical quantiles).

Spatial dependence was detected but not explicitly accounted for because of the lack of robustness in the methods available (Bini et al. 2009). The lack of independence between observations is the statistical equivalent of having too many degrees of freedom, and this can result in inflated p-values. Therefore, we were not able to use conventional hypothesis testing (i.e. null hypothesis significance testing; see Stephens et al. 2007, Diniz-Filho et al. 2008) to infer statistical significance. Instead, hypothesis testing was based on Akaike's information criterion (AIC) (Burnham \& Anderson 2002). AIC estimates the amount of information lost by using a given model to explain reality in relation to the underlying process. It is calculated as AIC $=$ $2 k-2 \ln (L)$, where $k$ is the number of parameters and $L$ is the maximized value of the likelihood function for the estimated model and, thus, describes the trade-off between model complexity $(k)$ and accuracy $(L)$. When comparing the AIC of several candidate models explaining the same response variable, the model with the lowest AIC will be the most parsimonious model with the minimum loss of information. In this manner, it is possible to investigate the statistical significance of adding additional parameters to a model by comparing the multivariate model with its nested model. By using this approach instead of null hypothesis significance testing, p-values become superfluous and we circumvent the potential influence of spatial dependence on the p-values (Richards 2005, Stephens et al. 2007). To test the statistical importance of the differences in AIC (delta AIC $\left[\Delta_{i}\right]$ ), we calculated the Akaike weight $\left(w_{i}\right)$, which is the estimated probability that a given model, within the range of candidate models, is the best model for the data (Burnham \& Anderson 2002, Richards 2005).

In order to discern and investigate the potential direct and indirect effects of temperature, 2 analyses were implemented. Firstly, variance partitioning 
(Legendre \& Legendre 1998) was performed on the multivariate linear regression model of the fraction of large phytoplankton versus temperature and nutrient availability, as well as on the multivariate linear regression model of the fraction of large phytoplankton versus temperature, nutrient availability and ocean region. This allowed for the variation to be split into individual and shared influences. Variance partitioning was performed using the $\mathrm{R}$ package 'vegan' version 2.0-5 (Oksanen et al. 2012), and the procedure for calculating the different fractions is thoroughly explained in the package documentation (vegandocs, 'partitioning.pdf'). In short, the proportion of $y$ (i.e. the fraction of large phytoplankton) explained by the explanatory variable $x_{1}$ (e.g. temperature) is found by regressing $y$ on $x_{1}$ while holding the other explanatory variables $x_{2}, x_{3} \ldots x_{i}$ constant with respect to $x_{1}$. From the individual fractions, the shared variation can be calculated by simple subtraction and addition (Legendre \& Legendre 1998). The results are presented as fractions inside a number of circles or rectangles corresponding to the number of explanatory variables. Fractions inside circles/ rectangles that do not overlap are interpreted as variation explained by that variable alone, and fractions inside circles/squares that overlap are interpreted as variation shared between the 2 or 3 variables in question.

Secondly, the potential direct effect of temperature was further explored by investigating the residuals left when the effects of inorganic nutrients had been statistically removed. This was done in 2 steps. In the first step, we modeled the fraction of large phytoplankton as a function of nutrient availability and extracted the residuals. In the second step, we modeled these residuals as a function of temperature to investigate the remaining pattern.

The ubiquity of the temperature effect was investigated for both the overall effect of changing temperature alone and for the shared effect of nutrients and temperature. In both analyses, we first grouped the stations according to ocean region (Northeastern Atlantic $n=37$, Northwestern Atlantic $n=21$, Eastern Atlantic $n=26$, Indian Ocean Sector $n=37$, Western Pacific $n=28$, Southern Ocean $n=37$, Eastern Pacific $n=26$, Western Atlantic $n=40$ ). If the temperature effect is universal, the effect (i.e. the slope of the linear regression models) should not differ significantly between ocean regions. To investigate the overall effect of changes in temperature, we constructed a hierarchy of 3 models. In the first model, we modeled the fraction of large phytoplankton as a function of temperature. In the second model, we modeled the fraction of large phytoplankton as a function of temperature while allowing different ocean regions to have different intercepts with the $y$-axis (i.e. by including the regional coding as a factor and thus allowing for differences in the average contribution of large phytoplankton between regions). In the third model, we modeled the fraction of large phytoplankton as a function of temperature while allowing the different regions to have different intercepts with the $y$-axis and to have different regression slopes (i.e. by including model interactions between regions and temperature and thus allowing differences in the effect of temperature between regions).

To investigate the potential direct effect of temperature on the fraction of large phytoplankton, we repeated the hierarchical 3-model setup, but instead of modeling the fraction of large phytoplankton, we modeled the residuals from the linear regression of the fraction of large phytoplankton as a function of nutrient availability. We then assessed the candidate models using AIC, delta AIC and Akaike weights.

\section{RESULTS}

\section{Macroecological patterns in the phytoplankton community size structure}

Three main macroecological patterns emerged from the exploratory data analysis (Fig. 1). Firstly, the fraction of large phytoplankton decreased with increasing temperature (Fig. 1A). Secondly, the fraction of large phytoplankton increased with increasing concentrations of both dissolved inorganic nitrogen (Fig. 1B) and phosphate (Fig. 1C). Thirdly, both dissolved inorganic nitrogen and phosphate decreased with increasing temperature (Fig. 1D,E). In addition, dissolved inorganic nitrogen increased with increasing phosphate (Fig. 1F). The Pearson correlation coefficients (Table 2) showed that all the explored factors co-varied, with especially strong correlations between dissolved inorganic nitrogen and phosphate $(r=0.84)$, dissolved inorganic nitrogen and temperature $(\mathrm{r}=-0.67)$, and phosphate and temperature $(\mathrm{r}=-0.65)$.

The modeling results showed an increase in model performance when temperature was included in addition to dissolved inorganic nitrogen and phosphate (Table 3 ; slopes and intercepts are presented in Table S1 in the Supplement at www.int-res.com/ articles/suppl/m497p025_supp.pdf). The support for the 3 multivariate models including temperature ranged from 10.1 to $45.5 \%$, whereas the support for 

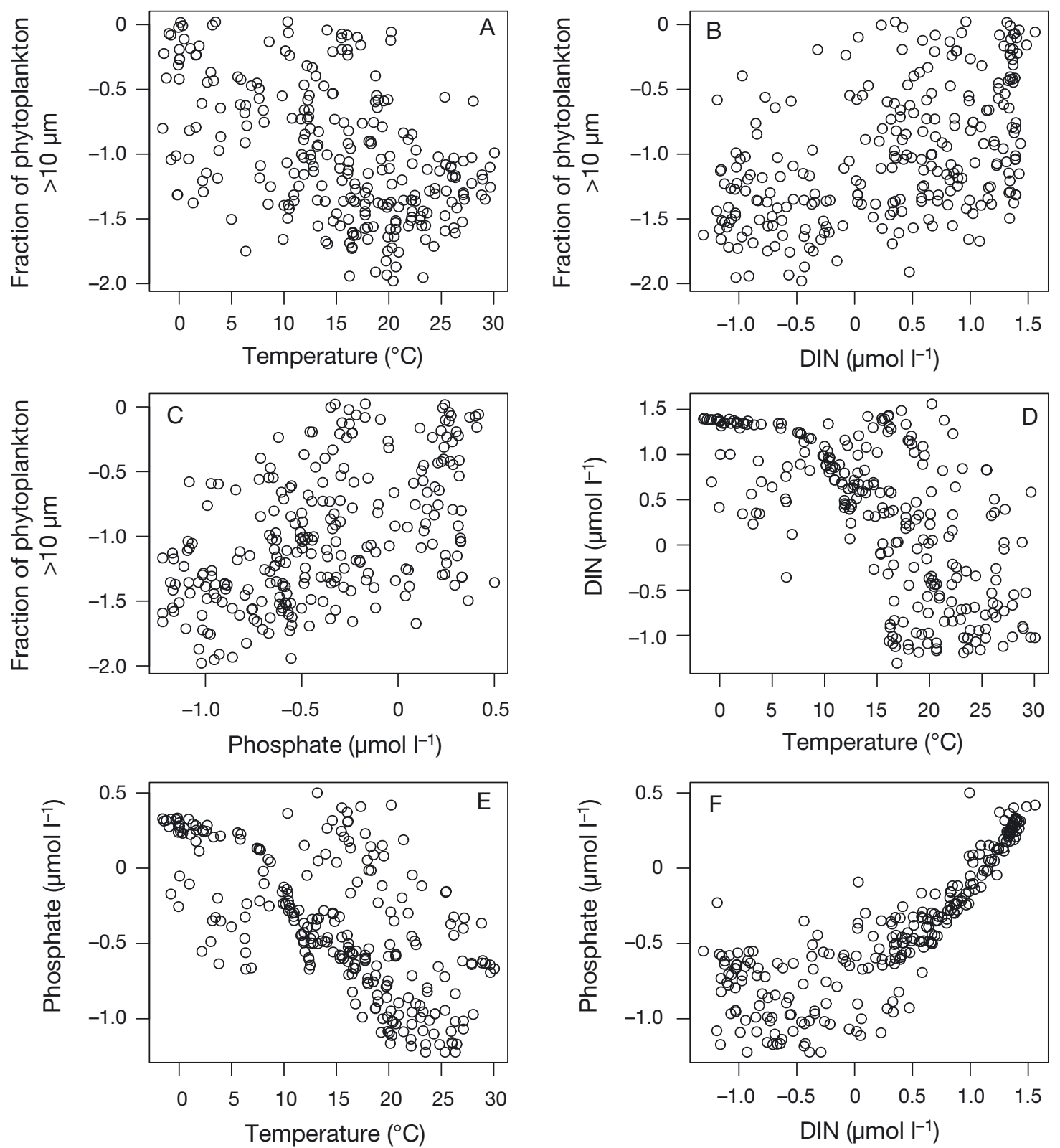

Fig. 1. Bivariate plots of the fraction of large phytoplankton versus: (A) temperature, (B) dissolved inorganic nitrogen (DIN) and (C) phosphate (redrawn from Hilligsøe et al. 2011), and (D) DIN versus temperature, (E) phosphate versus temperature and $(\mathrm{F})$ phosphate versus DIN. All variables with the exception of temperature have been log-transformed $(\mathrm{n}=260)$

Table 2. Pair-wise Pearson correlation coefficients for all variables. DIN: dissolved inorganic nitrogen

\begin{tabular}{|lccc|}
\hline Variable & $\begin{array}{c}\text { Fraction } \\
\text { of large } \\
\text { phytoplankton }\end{array}$ & Temperature & DIN \\
\hline Temperature & -0.48 & - & - \\
DIN & 0.50 & -0.67 & - \\
Phosphate & 0.51 & -0.65 & 0.84 \\
\hline
\end{tabular}

the nested models and the multivariate model excluding temperature was less than $1 \%$. From this, we conclude that temperature explains a significant part of the variation in the fraction of large phytoplankton which cannot be explained by nutrient availability.

According to the Akaike weights, the most parsimonious model for explaining the fraction of large phytoplankton included all 3 explanatory variables (temperature, dissolved inorganic and phosphate), 
Table 3. Results from model comparison of the fraction of large phytoplankton versus temperature, dissolved inorganic nitrogen (DIN) and phosphate using Akaike's information criterion (AIC), delta AIC $\left(\Delta_{i}\right)$ and Akaike weights $\left(w_{i}\right)$. See Table S1 in the Supplement (www.int-res.com/articles/suppl/m497p025_supp.pdf) for details on slopes and intercepts

\begin{tabular}{|c|c|c|c|c|c|c|c|}
\hline $\begin{array}{l}\text { Response } \\
\text { variable }\end{array}$ & $\begin{array}{l}\text { Explanatory } \\
\text { variable } 1\end{array}$ & $\begin{array}{l}\text { Explanatory } \\
\text { variable } 2\end{array}$ & $\begin{array}{l}\text { Explanatory } \\
\text { variable } 3\end{array}$ & $\mathrm{R}_{\text {adj. }}^{2}$ & AIC & $\Delta_{i}$ & $w_{i}$ \\
\hline \multirow{7}{*}{$\begin{array}{l}\text { Fraction of large } \\
\text { phytoplankton }\end{array}$} & Temperature & & & 0.23 & 318.7 & 21.2 & $<0.001$ \\
\hline & DIN & & & 0.25 & 310.9 & 13.4 & $<0.001$ \\
\hline & Phosphate & & & 0.24 & 313.0 & 15.5 & $<0.001$ \\
\hline & Temperature & DIN & & 0.29 & 297.8 & 3.1 & 0.101 \\
\hline & Temperature & Phosphate & & 0.29 & 300.6 & 0.3 & 0.407 \\
\hline & DIN & Phosphate & & 0.27 & 306.2 & 8.8 & 0.006 \\
\hline & Temperature & DIN & Phosphate & 0.30 & 297.4 & 0 & 0.485 \\
\hline
\end{tabular}

with a weight of $45.5 \%$. However, 2 other multivariate models including either temperature and dissolved inorganic nitrogen or temperature and phosphate were almost as good. Therefore, all subsequent analyses were performed for all 3 models. However, as the results were the same in all analyses, we only show the results from the best (i.e. the fraction of large phytoplankton versus temperature, dissolved inorganic nitrogen and phosphate). For the results of the other 2 set of analyses, see the supplement (www.int-res.com/articles/suppl/m497p025 _supp.pdf).

\section{Direct and indirect effects of temperature}

When the variation was partitioned, temperature explained $3 \%$ of the variation in the fraction of large phytoplankton (Fig. 2A). Phosphate and dissolved inorganic nitrogen combined (in the following referred to as inorganic nutrients) explained $6 \%$ of the variation, and the amount of variation explained by a combination of temperature and inorganic nutrients was $20 \%$ (Fig. 2A). When regional differences in the average contribution of large cells were accounted for (represented by the 2 rectangles in Fig. 2B), the variation explained by temperature alone increased to $8 \%$, whereas the variation explained by inorganic nutrients alone decreased to $1 \%$ and was restricted to the influence of phosphate (Fig. 2B). The amount of variation explained by both temperature and inorganic nutrients, however, remained relatively constant (23\%; Fig. 2B).

The $6 \%$ of variation explained by inorganic nutrients when spatial differences were not accounted for (Fig. 2A) suggests that a nutrient source not correlated with temperature has an important influence on the fraction of large phytoplankton. This potential nutrient effect increased to $8 \%$ when regional differences were accounted for, but $7 \%$ of this variation was shared with ocean region (Fig. 2B). This implies that an offset of the intercept with the $y$-axis in the model for each region (i.e. differences in the average contribution of cells larger than $10 \mu \mathrm{m}$ between regions) was equally good at explaining the variation as a temperature-independent nutrient effect, thus providing only weak evidence for a global independent nutrient effect.

However, the effect of temperature on the fraction of large cells was not correlated with ocean region without being correlated with inorganic nutrients at the same time (Fig. 2B). This indicates that the independent effect of temperature is independent from area-specific differences in average size, which could indicate that the temperature effect is universal. Thus, variance partitioning indicates that temperature has both a nutrientshared and a nutrient-independent effect on phytoplankton community size structure.
Fig. 2. Variance partitioning of the multivariate regression of the fraction of large phytoplankton versus (A) temperature, dissolved inorganic nitrogen (DIN) and phosphate and (B) temperature, DIN, phosphate and ocean region

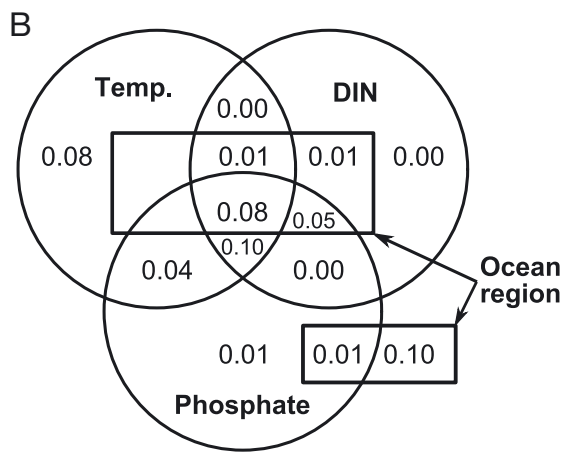


When the residuals from the linear regression of the fraction of large phytoplankton versus dissolved inorganic nitrogen and phosphate were regressed on temperature, a slight negative correlation was observed, which explained about $2 \%$ of the variation (Fig. 3). A negative relationship would be expected if the temperature effect on phytoplankton community size is direct. The regression intercepts the $x$-axis at about $15.0^{\circ} \mathrm{C}$, meaning that the model generally underestimates the fraction of large phytoplankton when the temperature is low (below $15^{\circ} \mathrm{C}$ ) and overestimates the fraction when the temperature is high (above $15^{\circ} \mathrm{C}$ ). It was not possible to test the weight of the model using AIC because there is no model to compare it with. However, a $t$-test showed that the slope was significantly different from zero $(p=0.017$, $\mathrm{df}=258$ ). In addition, in the analyses where the inorganic nutrients were investigated separately, the Akaike weights supported temperature as the best predictor for the remaining variation when the effect of dissolved inorganic nitrogen or phosphate had been statistically removed (see Tables S2 \& S3, and Figs. S3 \& S4 in the Supplement at www.int-res.com/ articles/suppl/m497p025_supp.pdf).

\section{Ubiquity of the temperature effect}

The results from analyses of the overall effect of warming (Table 4, Fig. 4A) and the nutrient-

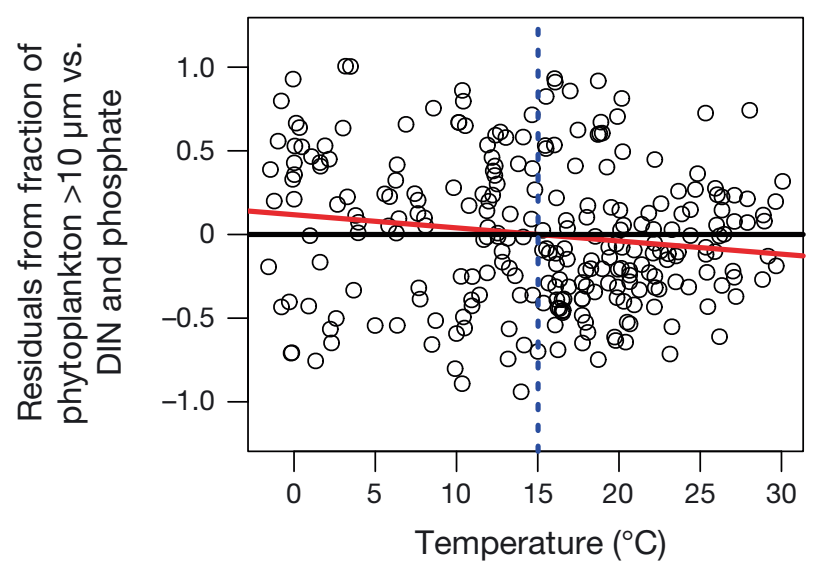

Fig. 3. Bivariate plot of the residuals (from a multivariate regression of the fraction of large phytoplankton versus dissolved inorganic nitrogen and phosphate) and temperature. The red and black lines represent the results from a linear regression model and the line where $y=0$, respectively. The vertical blue line represents the temperature where the regression line intercepts the black line and, thus, where the residuals change from being predominantly positive to predominately negative
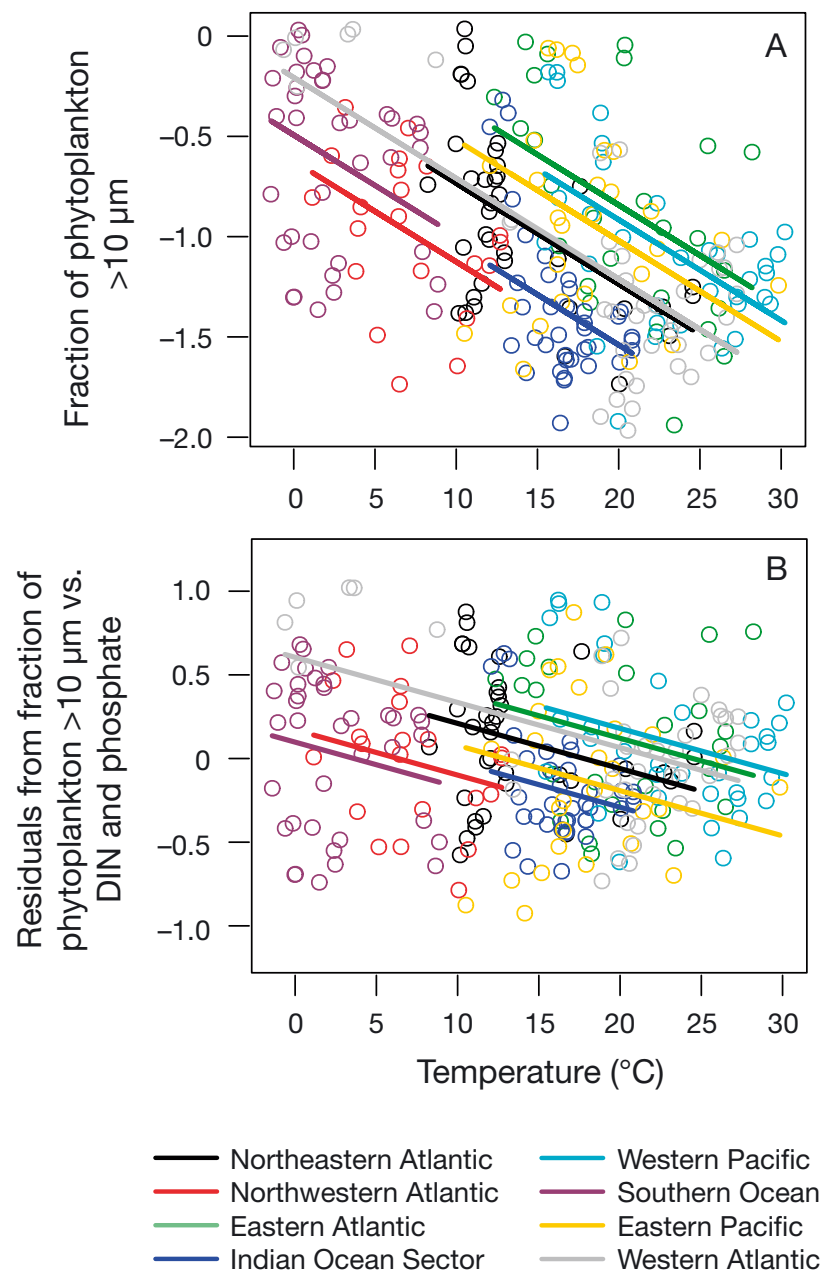

Fig. 4. Bivariate plots of (A) the fraction of large phytoplankton versus temperature and (B) the residuals (from a multivariate regression of the fraction of large phytoplankton versus dissolved inorganic nitrogen and phosphate) versus temperature. The colored lines represent the results from a linear regression model including the ocean region as a factor (slopes are forced to be the same according to the results shown in Tables 4 \& 5)

independent effect of increasing temperature (Table 5, Fig. 4B, see also Tables S4 \& S5, and Fig. S5 in the Supplement) both showed that the most parsimonious model for describing the fraction of large phytoplankton allowed for regional differences in the average contribution of phytoplankton larger than $10 \mu \mathrm{m}$, but with the same effect of temperature change in all ocean regions. In other words, although the biomass of large phytoplankton differed, an increase in temperature would lead to the same relative decrease in the fraction of large phytoplankton in all ocean regions investigated. According to the Akaike weights, the support for the models restricting the regression slope to be the same for all ocean 
Table 4. Results from model comparison of the fraction of large phytoplankton versus temperature and ocean region with and without including interactions using Akaike's information criterion (AIC), delta AIC $\left(\Delta_{i}\right)$ and Akaike weights $\left(w_{i}\right)$

\begin{tabular}{|c|c|c|c|c|c|c|c|c|}
\hline $\begin{array}{l}\text { Response } \\
\text { variable }\end{array}$ & $\begin{array}{l}\text { Explanatory } \\
\text { variable/Factor }\end{array}$ & Ocean region & Slope & Intercept & $\mathrm{R}_{\text {adj. }}^{2}$ & AIC & $\Delta_{i}$ & $w_{i}$ \\
\hline \multirow{3}{*}{$\begin{array}{l}\text { Fraction of large } \\
\text { phytoplankton }\end{array}$} & Temperature & & -0.03 & -0.56 & 0.23 & 318.7 & 51.9 & $<0.001$ \\
\hline & $\begin{array}{l}\text { Temperature } \\
\text { and region }\end{array}$ & $\begin{array}{l}\text { Eastern Atlantic } \\
\text { Eastern Pacific } \\
\text { Indian Ocean Sector } \\
\text { Northeastern Atlantic } \\
\text { Northwestern Atlantic } \\
\text { Southern Ocean } \\
\text { Western Atlantic } \\
\text { Western Pacific }\end{array}$ & -0.05 & $\begin{array}{r}0.14 \\
-0.04 \\
-0.56 \\
-0.25 \\
-0.65 \\
-0.52 \\
-0.23 \\
0.07\end{array}$ & 0.39 & 266.7 & 0 & 0.944 \\
\hline & $\begin{array}{l}\text { Temperature } \\
\text { and region } \\
\text { inclusive } \\
\text { interactions }\end{array}$ & $\begin{array}{l}\text { Eastern Atlantic } \\
\text { Eastern Pacific } \\
\text { Indian Ocean Sector } \\
\text { Northeastern Atlantic } \\
\text { Northwestern Atlantic } \\
\text { Southern Ocean } \\
\text { Western Atlantic } \\
\text { Western Pacific }\end{array}$ & $\begin{array}{l}-0.06 \\
-0.01 \\
-0.09 \\
-0.07 \\
-0.04 \\
-0.03 \\
-0.06 \\
-0.04\end{array}$ & $\begin{array}{r}0.38 \\
-0.70 \\
0.05 \\
-0.17 \\
-0.72 \\
-0.55 \\
-0.12 \\
-0.09\end{array}$ & 0.39 & 272.4 & 5.6 & 0.056 \\
\hline
\end{tabular}

Table 5. Results from model comparison of the residuals (from a linear regression of the fraction of large phytoplankton versus dissolved inorganic nitrogen and phosphate) versus temperature and ocean region with and without interaction using Akaike's information criterion (AIC), delta AIC $\left(\Delta_{i}\right)$ and Akaike weights $\left(w_{i}\right)$

\begin{tabular}{|c|c|c|c|c|c|c|c|c|}
\hline $\begin{array}{l}\text { Response } \\
\text { variable }\end{array}$ & $\begin{array}{l}\text { Explanatory } \\
\text { variable/Factor }\end{array}$ & Ocean region & Slope & Intercept & $\mathrm{R}_{\text {adj. }}^{2}$ & AIC & $\Delta_{i}$ & $w_{i}$ \\
\hline \multirow{3}{*}{$\begin{array}{l}\text { Residuals from } \\
\text { the fraction of } \\
\text { large phytoplank- } \\
\text { ton vs. dissolved } \\
\text { inorganic nitro- } \\
\text { gen and phos- } \\
\text { phate }\end{array}$} & Temperature & & -0.01 & 0.12 & 0.02 & 298.6 & 24.2 & $<0.001$ \\
\hline & $\begin{array}{l}\text { Temperature } \\
\text { and region }\end{array}$ & $\begin{array}{l}\text { Eastern Atlantic } \\
\text { Eastern Pacific } \\
\text { Indian Ocean Sector } \\
\text { Northeastern Atlantic } \\
\text { Northwestern Atlantic } \\
\text { Southern Ocean } \\
\text { Western Atlantic } \\
\text { Western Pacific }\end{array}$ & -0.03 & $\begin{array}{l}0.64 \\
0.33 \\
0.23 \\
0.46 \\
0.15 \\
0.08 \\
0.59 \\
0.70\end{array}$ & 0.13 & 274.3 & 0 & 0.956 \\
\hline & $\begin{array}{l}\text { Temperature } \\
\text { and region } \\
\text { inclusive } \\
\text { interactions }\end{array}$ & $\begin{array}{l}\text { Eastern Atlantic } \\
\text { Eastern Pacific } \\
\text { Indian Ocean Sector } \\
\text { Northeastern Atlantic } \\
\text { Northwestern Atlantic } \\
\text { Southern Ocean } \\
\text { Western Atlantic } \\
\text { Western Pacific }\end{array}$ & $\begin{array}{r}-0.01 \\
0.01 \\
-0.05 \\
-0.02 \\
-0.04 \\
-0.02 \\
-0.03 \\
-0.04\end{array}$ & $\begin{array}{r}0.38 \\
-0.36 \\
0.53 \\
0.35 \\
0.26 \\
0.07 \\
0.71 \\
0.99\end{array}$ & 0.13 & 280.5 & 6.1 & 0.044 \\
\hline
\end{tabular}

regions was 94.4 and $95.6 \%$ for the overall effect and the nutrient-independent effect of temperature, respectively, and with very little support for differentiated effects $(<6 \%)$. Thus, a model forcing the regression slope to be the same for all ocean regions performed significantly better than one allowing different slopes within each region. This strongly indicates that both the overall effect of warming and the nutrient-independent effect of increasing temperature are universal. 


\section{DISCUSSION}

It is well recognized that organisms become smaller with increasing temperature in both aquatic and terrestrial ecosystems (Sheridan \& Bickford 2011). The mechanisms behind this pattern are complex and differ between systems and at different biological scales (e.g. Daufresne et al. 2009). For phytoplankton communities in the ocean, both nutrient availability and temperature can theoretically explain this temperature-size pattern, but co-variance between these 2 factors has made it difficult to discern the individual effects. This has led some authors to suggest that a potential direct effect of temperature on phytoplankton community size structure can be ignored because the effect of resource utilization (primarily nutrient availability) is so large in comparison (e.g. Marañón et al. 2012). Others have apparently accepted that nutrient availability is the most important factor and have not sought to investigate a potential direct temperature effect, focusing instead on nutrient availability and/or predation (e.g. Armstrong 1994, Winder et al. 2009). In this study, we provide evidence that temperature effects not associated with nutrient availability may play a significant role in controlling phytoplankton community size structure.

Variance partitioning revealed that a large part of the explained variation in the relative contribution of large phytoplankton was shared between nutrient availability and temperature. Although statistics are not able to distinguish between the influences of 2 co-linear variables in the shared variation space, we can hypothesize with respect to the causal relationship underlying this pattern. Heat input (leading to increased temperature in surface waters) influences the strength of water column stratification, which, in turn, decreases mixing between deeper nutrient-rich waters and the surface and, consequently, reduces the amount of inorganic nutrients being transported to the euphotic zone (Kamykowski \& Zentara 1986, Genin et al. 1995, Behrenfeld et al. 2006). On a global scale, where temperature correlates with latitude, the temperature gradient (i.e. decreasing temperature with increasing distance from the equator) can be interpreted as a gradual transition from areas with permanent stratification and a limited flux of inorganic nutrients over the pycnocline to areas where annual deep mixing facilitates a nutrient flux from the deep waters to the surface (Kamykowski \& Zentara 1986, Behrenfeld et al. 2006). From this, we hypothesize that the pattern of a general increase in nutrient availability with de- creasing temperature (Fig. 1D,E) as well as the explained variation of the contribution of large cells that is shared between nutrient availability and temperature $(23 \%$; Fig. 2B) may be due to this causal link. This interpretation is consistent with that made in several other studies at varying scales (e.g. Genin et al. 1995, Li 1998, Sigman et al. 2004, Finkel et al. 2005). Therefore, instead of representing statistical uncertainty, the amount of explained variation shared at this global scale (and in the above, described as a nutrient-shared effect) could, conceivably, be an indirect effect of temperature on the fraction of large phytoplankton, where temperature controls the availability of inorganic nutrients in the euphotic zone.

This study suggests that the nutrient-independent effect of temperature on phytoplankton community size structure, while smaller than the effect of nutrient availability, is of an order that it should not be ignored. When spatial differences are accounted for, the variation in the fraction of large phytoplankton explained by the nutrient-independent temperature effect becomes 8\% (compared with 23\% being explained by the nutrient-shared effect). Thus, although it is usually assumed that the relationship between the fraction of large phytoplankton and temperature is related to the effect of temperature on nutrient availability, results from the present study suggest that about one-fourth of this variation in the fraction of large phytoplankton is unrelated to the nutrient availability and can be explained by temperature alone.

The evidence presented here suggests an important nutrient-independent effect of temperature on phytoplankton community size structure, operating at the level of the global phytoplankton community. Previous studies suggesting a possible direct temperature effect on phytoplankton size have been based on more spatially confined data sets, e.g. mesocosm experiments (Yvon-Durocher et al. 2011, Peter \& Sommer 2012) and picophytoplankton in the Atlantic Ocean (Morán et al. 2010). These earlier studies, combined with our own, suggest that the influence of the nutrient-independent and potentially direct effect of temperature on phytoplankton community size structure may be much larger than has previously been realized.

Adding spatial information to the applied statistical models revealed a consistent relationship between temperature increase and phytoplankton community size structure in all of the major oceanic regions represented in the data set. This suggests that the response to temperature is universal. Although the 
relationships between temperature, productivity and size composition have been shown to have opposing directions at different local or regional scales (e.g. Polovina et al. 1995), the present study suggests that these effects average out when investigated on a sufficiently large scale, with an overall pattern emerging of a negative response in contribution of large cells to phytoplankton biomass as temperature increases. Although the temperature-size pattern may vary at local scales, the macroecological approach used in this study suggests that a nutrient-independent temperature effect is present in all regional ocean systems studied and that this effect should be included (or at least considered) when modeling of the size composition is attempted.

The use of in situ nutrient concentrations as a proxy for nutrient availability and supply to phytoplankton is a key assumption in our study, and therefore deserves consideration here. There are a number of reasons why nutrient concentrations can become uncoupled from nutrient supply and, thus, become inappropriate for testing the effect of nutrient supply on phytoplankton community size structure. These reasons are often spatially or temporally specific (e.g. local/seasonal mixing conditions, stage of bloom, etc.). However, these temporally and spatially confined disconnections between nutrient concentrations and nutrient supply should average out if investigated with a sufficiently large data set. In our data set, the linear models of the fraction of large phytoplankton versus nutrient availability or temperature show the same magnitude of variance, and when the residuals are investigated, no visible pattern emerges. This indicates that the error is equally distributed along both the nutrient and temperature gradients. It is not possible to quantify to what extent the residuals are due to discontinuity. However, the investigation shows that the magnitude of the problem is the same for dissolved inorganic nitrogen, phosphate and temperature. Thus, it is fair to treat the residuals as stochastic noise and conclude that there are no parts of the gradients that are especially prone to discontinuity errors and, thus, that the errors have no influence on the slopes. Ultimately, the residual patterns indicate that the data set is sufficiently large to average out spatially and temporally confined discontinuities (for both nutrient concentrations and temperature).

Our conclusions appear to contradict those of Marañón et al. (2012). In that study, the authors presented a meta-analysis investigating phytoplankton community size structure in relation to temperature and primary production, where primary production was used as proxy for resource use. They found that 62 and $2 \%$ of the variance in the relative contribution of microphytoplankton to total phytoplankton biomass could be explained by the magnitude of primary production and temperature, respectively. Although temperature did explain a significant part of the variation in 5 out of 6 models in their study, they concluded that temperature did not have a direct effect on phytoplankton community size structure and that no single, universal effect of ocean warming on phytoplankton size should be anticipated.

Their conclusions, however, build on several assumptions. The authors report that the temperature-size rule was unable to account for the variation in community size structure explained by temperature alone. They found that the temperature-size rule could only explain a $0.04 \%{ }^{\circ} \mathrm{C}^{-1}$ and $0.28 \%{ }^{\circ} \mathrm{C}^{-1}$ reduction in picophytoplankton and microphytoplankton, respectively, compared with the observed $0.8 \%{ }^{\circ} \mathrm{C}^{-1}$ and $0.5 \%{ }^{\circ} \mathrm{C}^{-1}$. From this, they conclude that at least part of the observed correlation between temperature and phytoplankton size structure reflects the effects of other variables that co-vary with temperature. This argument, however, builds on the assumptions that there is no change in species composition and that the temperature-size rule (i.e. the $2.5 \% \mathrm{C}^{-1}$ volume decrease defined by Atkinson et al. 2003 ) is the only possible direct effect of temperature. It is highly unlikely that the phytoplankton community size structures reported by Marañón et al. (2012) are unaffected by shifts in species composition, and several other direct and indirect effects of temperature have been proposed (Daufresne et al. 2009, Finkel et al. 2010). Therefore, it should not be surprising that the temperature-size rule (as defined by Atkinson et al. 2003) fails to explain all the variation observed. However, if the temperature-size rule is extended to include species shifts and/or intraspecific genetic variability, the expected decrease in cell size should be much larger. Accordingly, Peter \& Sommer (2012) found a 4 -fold decrease in size for each order of magnitude increase in temperature, which is a much stronger temperature effect, and this may be a better estimation of the temperature effect in natural assemblages than the rule proposed by Atkinson et al. (2003).

In addition, Marañón et al. (2012) observed that increasing the availability of a limiting nutrient would result in increased dominance of larger species regardless of the temperature. The apparent departure from the macroecological temperature-size relationship (i.e. dominance of small phytoplankton 
cells at high temperature) when limiting nutrients are added in warm water (e.g. the IronEx II experiment; Cavender-Bares et al. 1999) cannot, however, serve as an argument against a direct temperature effect. The mechanisms linking nutrient availability and community mean cell size are primarily linked to the competitive differences associated with area-tovolume ratio and thickness of the diffusion boundary layer (Tilman et al. 1982, Kiørboe 1993). Although these conditions are probably influenced by temperature, there is no a priori reason to suspect fundamental differences between cold and warm waters when nutrients are added. In other words, adding limiting nutrients lessens the competitive advantage of being small regardless of the in situ temperature, and this can lead to dominance of large cells in warm waters if nutrient availability allows it.

Correlation does not, of course, necessarily imply causality. Another unknown factor, correlated with temperature, could be the real forcing factor behind what we here are interpreting as a direct effect of temperature on phytoplankton community size structure. The fact that we identify an apparently universal relationship between the importance of large phytoplankton cells and a nutrient-independent temperature effect, however, implies that whatever factor is resulting in this effect should not correlate with nutrient availability and should have the same effect in all oceanic regions. We can think of several factors that could potentially influence phytoplankton community size structure and scale with temperature (i.e. sinking speed, nutrient supply rate, light, mixing regime, etc.). However, none of these can be expected to correlate with the nutrient-independent effect of temperature we identify here and, at the same time, have the same effect on phytoplankton community size structure in all ocean regions.

Light, for example, might be expected to correlate with temperature in the euphotic zone as both are to a large extent controlled by solar irradiation. Photosynthetically active radiation can be approximated over depth by a decreasing exponential function. Temperature, however, is often relatively constant in the upper layers of the ocean due to wind-induced mixing. Thus, light and temperature are often not well correlated. Furthermore, the effect of increasing light intensity on phytoplankton community composition is probably very different between low-latitude waters, where the water column is permanently stratified and light is not the limiting resource, and midlatitude waters experiencing seasonal stratification. Thus, the apparently universal relationship we find here between temperature and the size structure of phytoplankton communities strongly indicates that light is not responsible for the potential direct effect observed here. However, we fully acknowledge that light can play an important role in controlling phytoplankton community size structure at local and regional scales.

It should also be noted that there is empirical evidence for the nutrient-independent effect on community phytoplankton size structure being mediated directly by temperature. A temperature-size relationship has been shown for individual species in controlled laboratory studies (Ellegaard et al. 2002, Atkinson et al. 2003) as well as for mixed communities in mesocosm experiments (Yvon-Durocher et al. 2011, Peter \& Sommer 2012). In addition, a direct temperature effect can be explained theoretically by combining the effect of temperature changes on the rate of biological activity (Eppley 1972, Moisan et al. 2002, Brown et al. 2004) with nutrient competition theory (Tilman et al. 1982, Kiørboe 1993). Temperature increases will have a universal effect, leading to increased metabolism in all ocean regions. This would lead to an increase in resource demand for all phytoplankton groups. As it is highly unlikely that the temperature increase is accompanied by a compensating increase in resources, a temperatureinduced rise in metabolism could be a plausible explanation for the decrease in the dominance of large species with increasing temperature observed here.

These arguments are analogous to arguments put forth to describe the nutrient-dependent effect on phytoplankton community size composition. Observations of correlation have been used to argue that changes in phytoplankton community structure are explained by nutrient availability through thermal stratification (Finkel et al. 2005, 2007, Winder et al. 2009). Just as in the case of the nutrient-independent effect in the relationship of community size composition to temperature we describe here, such correlations do not necessary imply causality. Thermal stratification is related to mixing regime and sinking speed, both of which may affect the phytoplankton community size structure, although nutrient availability seems to be the most plausible explanation. Thus, while our study does not unequivocally identify a direct temperature effect on phytoplankton community size structure, it does identify a nonnutrient effect on community size structure that correlates with temperature and that is of a statistical magnitude that makes it potentially important in understanding what shapes phytoplankton community size composition. 
Another mechanism by which temperature may affect phytoplankton community size structure directly is through predation. In the residual analysis (Fig. 2B), we note that the regression intercept corresponds well with the temperature $\left(15^{\circ} \mathrm{C}\right)$ at which the maximum growth rate of heterotrophic protists is reported to exceed the maximum growth rate of autotrophic protists (Rose \& Caron 2007). If an increase in metabolic rate is the only mechanism underlying the direct effect of temperature, we would expect the regression slope, averaged over all oceanic regions, to intercept the $x$-axis at $0^{\circ} \mathrm{C}$. The offset noted here may indicate that resource competition between autotrophs and heterotrophs and/or temperature-linked predation are important factors, in addition to intraspecific and interspecific competition in the phytoplankton community, in controlling phytoplankton community size structure in the open ocean. Predation is known to affect phytoplankton community size structure (Armstrong 1994, Schartau et al. 2010) and a differential response in growth rate of autotrophs and heterotrophs to temperature increase may, therefore, prove to be an important direct mechanism.

The temperature effect reported here would imply that global ocean warming can be expected to cause a shift in the size structure of the global phytoplankton community towards smaller individuals. This will affect food web structure, with a smaller part of the primary production being transported to higher trophic levels (Michaels \& Silver 1988, Petchey et al. 2008, Hilligsøe et al. 2011). Instead, a larger part of the primary production will be expected to enter the microbial loop, leading to a decrease in the efficiency of the biological pump and therefore the amount of carbon being transported from the surface to the deep layers of the ocean (Azam et al. 1983, Fenchel 2008). This will influence the global carbon cycle and, thus, climate change through a likely positive feedback that would further strengthen global warming. Although current climate models already predict positive feedback from the increasing temperature in the ocean, these predictions build on the assumption that the main mechanism by which temperature affects phytoplankton size structure is the mediation of nutrient availability (IPCC 2007). The empirical evidence of a universal and direct effect of temperature on phytoplankton community size structure presented in this study suggests that the indirect effect of temperature, mediated through nutrient availability, only tells part of the story, and that current climate models might underestimate the effect of temperature on the carbon sink in a warming ocean.
Acknowledgements. The present work was carried out using data collected on the Galathea 3 expedition under the auspices of the Danish Expedition Foundation, where data collection was supported by the Nordea Fund, the Villum Kann Rasmussen Fund, the Carlsberg Fund, the Knud Petersen Fund, The Danish Expedition Fund and The Danish Research Council for Nature and Universe. This study was further supported by a grant from the Danish Research Foundation. We thank William Li (Bedford Institute for Oceanography) and Dieter Wolf-Gladow (Alfred Wegener Institute) for commenting on the manuscript. This is Galathea 3 contribution no. P101.

\section{LITERATURE CITED}

Armstrong RA (1994) Grazing limitation and nutrient limitation in marine ecosystems: steady state solutions of an ecosystem model with multiple food chains. Limnol Oceanogr 39:597-608

Atkinson D (1994) Temperature and organism size - a biological law for ectotherms? Adv Ecol Res 25:1-58

Atkinson D, Ciotti BJ, Montagnes DJS (2003) Protists decrease in size linearly with temperature: ca. $2.5 \%{ }^{\circ} \mathrm{C}^{-1}$. Proc R Soc Lond B 270:2605-2611

Azam F, Fenchel T, Field JG, Gray JS, Meyer-Reil LA, Thingstad F (1983) The ecological role of water-column microbes in the sea. Mar Ecol Prog Ser 10:257-263

Behrenfeld MJ, O'Malley RT, Siegel DA, McClain CR and others (2006) Climate-driven trends in contemporary ocean productivity. Nature 444:752-755

> Bini LM, Diniz-Filho JA, Rangel TFLVB, Akre TSB and others (2009) Coefficient shifts in geographical ecology: an emperical evaluation of spatial and non-spatial regression. Ecography 32:193-204

Brown J, Gillooly J, Allen A, Savage V, West G (2004) Toward a metabolic theory of ecology. Ecology 85: 1771-1789

Burnham K, Anderson D (2002) Model selection and multimodel inference: a practical information-theoretic approach. Springer, New York

- Cavender-Bares KD, Mann EL, Chisholm SW, Ondrusek ME, Bidigare RR (1999) Differential response of equatorial pacific phytoplankton to iron fertilization. Limnol Oceanogr 44:237-246

> Daufresne M, Lengfellner K, Sommer U (2009) Global warming benefits the small in aquatic ecosystems. Proc Natl Acad Sci USA 106:12788-12793

> Diniz-Filho JAF, Rangel TFLVB, Bini LM (2008) Model selection and information theory in geographical ecology. Glob Ecol Biogeogr 17:479-488

Ellegaard M, Lewis J, Harding I (2002) Cyst-theca relationship, life cycle, and effects of temperature and salinity on cyst morphology of Gonyaulax baltica sp. nov. (Dinophyceae) from the Baltic Sea area. J Phycol 42: 1028-1039

Eppley RW (1972) Temperature and phytoplankton growth in the sea. Fish Bull 70:1063-1085

Fenchel T (2008) The microbial loop - 25 years later. J Exp Mar Biol Ecol 366:99-103

Finkel ZV, Katz ME, Wright JD, Schofield OME, Falkowski PG (2005) Climatically driven macroevolutionary patterns in the size of marine diatoms over the Cenozoic. Proc Natl Acad Sci USA 102:8927-8932 
Finkel ZV, Sebbo J, Feist-Burkhardt S, Irwin AJ and others (2007) A universal driver of macroevolutionary change in the size of marine phytoplankton over the Cenozoic. Proc Natl Acad Sci USA 104:20416-20420

Finkel ZV, Beardall J, Flynn KJ, Quigg A, Rees TAV, Raven JA (2010) Phytoplankton in a changing world: cell size and elemental stoichiometry. J Plankton Res 32:119-137

Genin A, Lazar B, Brenner S (1995) Vertical mixing and coral death in the Red Sea following the eruption of Mount Pinatubo. Nature 377:507-510

Gillooly JF, Brown JH, West GB, Savage VM, Charnov EL (2001) Effects of size and temperature on metabolic rate. Science 293:2248-2251

Grasshoff K, Erhardt M, Kremling K (1983) Methods of seawater analysis, 2nd edn. Verlag Chemie, Weinheim

Hillebrand $\mathrm{H}$ (2011) Temperature mediates competitive exclusion and diversity in benthic microalgae under different N:P stoichiometry. Ecol Res 26:533-539

Hilligsøe KM, Richardson K, Bendtsen J, Sørensen L, Nielsen TG, Lyngsgaard MM (2011) Linking phytoplankton community size composition with temperature, plankton food web structure and sea-air $\mathrm{CO}_{2}$ flux. DeepSea Res Part I 58:826-838

IPCC (2007) Contribution of Working Group I to the Fourth Assessment Report of the Intergovernmental Panel On Climate Change. Solomon S, Qin D, Manning M, Chen Z, Marquis M, Averyt KB, Tignor M, Miller HL (eds). Cambridge University Press, New York, NY

Kamykowski D, Zentara SJ (1986) Predicting plant nutrient concentrations from temperature and sigma-t in the upper kilometer of the world ocean. Deep-Sea Res Part I 33:89-105

Kiørboe T (1993) Turbulence, phytoplankton cell size, and the structure of pelagic food webs. Adv Mar Biol 29:1-72

> Laws EA, Falkowski PG, Smith WO Jr, Ducklow H, McCarthy JJ (2000) Temperature effects on export production in the open ocean. Global Biogeochem Cycles 14:1231-1246

Legendre P, Legendre L (1998) Numerical ecology, 2nd English edn. Elsevier, Amsterdam

> Li WKW (1998) Annual average abundance of heterotrophic bacteria and Synechococcus in surface ocean waters. Limnol Oceanogr 43:1746-1753

Marañón E, Cermeño P, Latasa M, Tadonléké RD (2012) Temperature, resources, and phytoplankton community size structure in the ocean. Limnol Oceanogr 57: 1266-1278

> Michaels S, Silver M (1988) Primary production, sinking fluxes and the microbial web. Deep-Sea Res Part I 35: 473-490

Moisan JR, Moisan TA, Abbot MR (2002) Modelling the effect of temperature on the maximum growth rate of phytoplankton populations. Ecol Model 153:197-215

Editorial responsibility: Graham Savidge, Portaferry, UK
Morán XAG, López-Urrutia Á, Calvo-Díaz A, Li WKW (2010) Increasing importance of small phytoplankton in a warming ocean. Glob Change Biol 16:1137-1144

Oksanen J, Blanchet G, Kindt R, Legendre P and others (2012) Vegan: community ecology package, version 2.05. Available at http://cran.r-project.org/package=vegan

> Petchey OL, Beckerman AP, Riede JO, Warren PH (2008) Size, foraging, and food web structure. Proc Natl Acad Sci USA 105:4191-4196

> Peter KH, Sommer U (2012) Phytoplankton cell size: intraand interspecific effects of warming and grazing. PLoS ONE 7:e49632

> Polovina JJ, Mitchum GT, Evans GT (1995) Decadal and basin-scale variation in mixed layer depth and the impact on the biological production in the Central and North Pacific, 1960-88. Deep-Sea Res Part I 42:1701-1716

R Core Development Team (2012) R: a language and environment for statistical computing. R Foundation for Statistical Computing, Vienna

> Reuman DC, Mulder C, Raffaelli D, Cohen JE (2008) Three allometric relations of population density to body mass: a theoretical integration and empirical tests in 149 food webs. Ecol Lett 11:1216-1228

Richards SA (2005) Testing ecological theory using the information-theoretic approach: examples and cautionary results. Ecology 86:2805-2814

> Rose JM, Caron DA (2007) Does low temperature constrain the growth rates of heterotrophic protists? Evidence and implications for algal blooms in cold waters. Limnol Oceanogr 52:886-895

Schartau M, Landry MR, Armstrong RA (2010) Density estimation of plankton size spectra: a reanalysis of IronEx II data. J Plankton Res 32:1167-1184

Sheridan JA, Bickford D (2011) Shrinking body size as an ecological response to climate change. Nature Clim Change 1:401-406

Sigman DM, Jaccard SL, Haug GH (2004) Polar ocean stratification in a cold climate. Nature 428:59-63

Sommer U, Lengfellner K (2008) Climate change and the timing, magnitude, and composition of the spring bloom. Glob Change Biol 14:1199-1208

> Stephens PA, Buskirk SW, del Rio CM (2007) Inference in ecology and evolution. Trends Ecol Evol 22:192-197

Tilman D, Kilham SS, Kilham P (1982) Phytoplankton community ecology: the role of limiting nutrients. Annu Rev Ecol Syst 13:349-372

> Winder M, Reuter JE, Scladow SG (2009) Lake warming favours small-sized planktonic diatom species. Proc R Soc Lond B 276:427-435

> Yvon-Durocher G, Montoya JM, Trimmer M, Woodward G (2011) Warming alters the size spectrum and shifts the distribution of biomass in freshwater systems. Glob Change Biol 17:1681-1694

Submitted: May 16, 2013; Accepted: October 6, 2013

Proofs received from author(s): December 3, 2013 